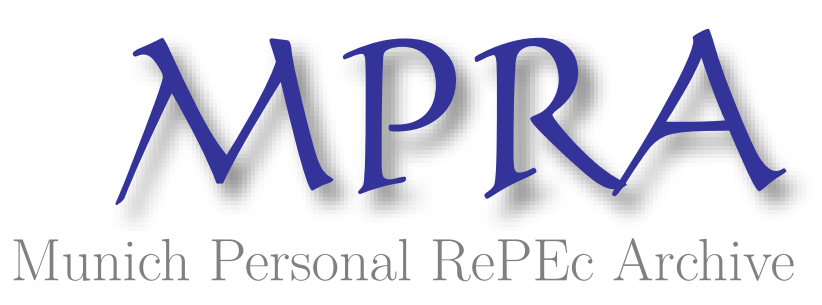

\title{
Is Germany's Energy Transition a case of successful Green Industrial Policy? Contrasting wind and solar PV
}

Pegels, Anna and Lütkenhorst, Wilfried

German Development Institute / Deutsches Institut für Entwicklungspolitik (DIE)

2014

Online at https://mpra.ub.uni-muenchen.de/57827/

MPRA Paper No. 57827, posted 11 Aug 2014 15:03 UTC 


\title{
Is Germany's Energy Transition a case of successful Green Industrial Policy? Contrasting wind and solar PV
}

\author{
Anna Pegels ${ }^{a}$ (corresponding author), Wilfried Lütkenhorst ${ }^{a}$ \\ ${ }^{a}$ German Development Institute / Deutsches Institut für Entwicklungspolitik (DIE) \\ Tulpenfeld 6 \\ 53113 Bonn \\ Germany \\ anna.pegels@die-gdi.de
}

Version of 11 March 2014

NOTICE: this is the authors' version of a work that was accepted for publication in Energy Policy. Changes resulting from the publishing process, such as peer review, editing, corrections, structural formatting, and other quality control mechanisms may not be reflected in this document. Changes may have been made to this work since it was submitted for publication.

Acknowledgements: The research project leading to the present article was funded by the International Institute for Sustainable Development (IISD). A comprehensive report is available at http://www.iisd.org/publications/pub.aspx?pno=2893. 


\begin{abstract}
:
In this paper, we address the challenge of Germany's energy transition (Energiewende) as the centrepiece of the country's green industrial policy. In addition to creating a sustainable foundation for Germany's energy supply and contributing to global climate change objectives, the Energiewende is intended to create a leading position for German industry in renewable energy technologies, boost innovative capabilities and create employment opportunities in future growth markets. The success in reaching these aims, and indeed the future of the entire concept, is fiercely debated.

The paper aims to provide an up-to-date and balanced assessment of costs and benefits of renewable energy support measures. However, since costs and benefits can differ widely between targeted technologies, we compare solar photovoltaic (PV) and wind energy to illustrate critical elements of green industrial policy success. We find mixed evidence that Germany reaches its green industrial policy aims at reasonable costs. Wind energy seems to perform better against all policy objectives, while the solar PV sector has come under intense pressure from international competition. However, this is only a snapshot of current performance, and a dynamic and systemic perspective may nonetheless make the support of various renewable energy sources advisable.
\end{abstract}

Keywords: Green industrial policy; renewable energies; Germany 


\section{Introduction}

We know that, if we are to maintain acceptable living conditions for ourselves and our descendants, there will need to be a radical change in the way we use the natural resources to be found on our planet. Green industrial policy, that is, government intervention to hasten the restructuring of the economy towards environmental sustainability (Pegels, 2014), is a particularly suitable instrument to achieve this radical and long-term transition. Governments must intervene, because market mechanisms such as prices alone are failing to bring about the drastic and fast changes to the very fabric of our economies required for the protection of our planet (Hallegatte et al., 2013). Linking environmental protection to such traditional aims of industrial policy as competitiveness, job creation and innovation as 'co-benefits' may help it to win supporters. Environmental sustainability on its own has failed to become a driver of structural change in most countries.

However, the multiplicity of aims also renders green industrial policy making more complex. The aims are not always in harmony, and vested interests may prevent the required shift from polluting to clean economic activities. The energy sector is a prime example for these challenges. Energy literally powers economic development. Hence, energy policy must be considered as a cornerstone of any industrial policy, regardless of the latter's specific objectives, approach and implementation. Through its impact on energy availability in general, and through more specific measures targeting the promotion of different energy sources and their relative prices, energy policy has a strong influence on an economy's competitiveness, employment, sectoral diversification patterns, trade position and longterm technological trajectory.

This has always been the case. However, it applies even more powerfully in a scenario of planetary boundaries, global material resource scarcity and climate change that together call for a radical rethinking of the manner in which energy has been generated, distributed and consumed so far. While notions and concepts of a Third, or New, or Next Industrial Revolution are currently proliferating in various manifestations (Rifkin, 2011; Dosi \& Galambos, 2013; The Economist, 2012; Marsh, 2012; Andersen, 2012), it is evident that a long-term transition to a decarbonized energy scenario has to be part and parcel of building a sustainable future.

At the same time, energy policy is invariably designed and applied within a veritable minefield of stakeholders, interests, conflicts and alliances. It requires a long-term planning perspective and a holistic look at political, social, economic and technological challenges and scenarios. Above all, energy policy fundamentally determines a country's future basic infrastructure for decades ahead and thus creates strong lock-in effects and path dependency. It is a field of economic policy that does not lend itself to frequent shifts and reorientations unless huge investments are to be turned into stranded and wasted assets.

The above applies in particular in the context of the German case. The country is in the midst of a fundamental energy transition (Energiewende), which involves a complete phase-out of nuclear energy and a deliberate policy of reliance on renewable energy sources. This 
necessitates a basic consensus on societal preferences, resulting energy policy aims and the way ahead. In a somewhat stylized perspective, German society has generally been characterized by a strong technological risk aversion; more specifically, the nuclear exit policy commands broad political and popular support and such technological options as carbon capture and storage or hydraulic fracturing meet with strong public opposition. Also, climate change considerations figure high on the agenda of societal concerns. The issue of energy prices currently somewhat dominates the debate around energy policy, both for industrial and household consumption, and this has become one of the essential yardsticks for assessing the progress and prospects of the ongoing energy transition towards renewables.

Against this backdrop, the present paper reviews the German policy in support of raising the share of renewables in the energy mix against the background of the multidimensional set of social, economic, technological and ecological objectives which is inherent to green industrial policy. The swift transition to various renewable energy sources primarily for electricity generation (but also increasingly for heat generation and fuels) constitutes the centrepiece of German energy policy. For the purpose of this paper, an exclusive focus on electricity generation is adopted. The paper aims to provide an up-to-date and balanced assessment of what has become a fierce controversy. However, costs and benefits of policy measures can differ widely between targeted technologies. Therefore, we compare solar photovoltaic (PV) and wind energy to illustrate critical elements of green industrial policy success.

Section 2 presents objectives and measures of the energy transition as the cornerstone of green industrial policy in Germany, and presents the methods used to assess their costs and benefits. This is a complex undertaking fraught with diverse methodological challenges. Often, political positions and lobbying guide seemingly technical calculations. An attempt is thus made to rely to the extent possible on quantitative assessments and clearly spell out their underlying assumptions. Since results can differ largely among technologies, we concentrate on wind and solar PV energy as exemplary cases. Section 3 presents and discusses the results of the assessment for both technologies separately and in direct comparison. Section 4 concludes by placing the discussion in a systemic perspective of Germany's green industrial policy.

\section{Methods}

\subsection{The German Energy Transition: Objectives and Measures}

A national priority project of the highest order, such as the energy transition, is invariably governed by a complex set of objectives. To some extent, these have been officially pronounced and codified in legal documents. In addition, they can be derived from ministerial policy statements and publications.

With the Renewable Energy Sources Act (EEG) being the most important green energy policy law, its expressed policy objectives deserve prime consideration (Renewable Energy Sources Act - EEG 2012). In its Article 1 on the purpose of the law, the following objectives are listed: 
- "Sustainable development of energy supply."

- "Protecting our climate and the environment."

- "Reducing the costs of energy supply to the national economy."

- "Further development of technologies for the generation of electricity from renewable energy sources."

In various publications, statements and speeches by the relevant Government entities (Ministry of Environment, Nature and Nuclear Safety; Ministry of the Economy and Technology, as well as the Chancellor herself), the energy transition is portrayed as contributing to:

- Strengthening Germany's leading global market position for climate-friendly technologies.

- Ensuring reliable and affordable energy supply to maintain competitiveness.

- Boosting innovative capabilities of industry.

- Creating employment opportunities from renewable energy development.

- Saving scarce resources and reducing import dependency from fossil fuels.

In general, renewable electricity promotion policies in Germany are built around the core concept of feed-in tariffs (FiT), complemented by dedicated renewables loan programmes, as well as various types of support to research and development activities (R\&D) (direct funding, demonstration projects, innovation alliances etc.) as part of science and innovation policies. Neither local content policies nor government procurement or renewables purchase obligations (outside the EEG-FiT, which constitutes a de facto unlimited purchasing commitment) are in place at either the federal or the state level. The German renewables policy scenario can thus best be characterized as being a combination of a robust legal and policy framework, sustained funding of a diversified set of research institutions and an emphasis on price-based rather than quota-based investment incentives.

Presently (early 2014), a fierce debate is raging in Germany on the impact and further adjustment needs of the EEG (see, for example, Diekmann et al., 2012a, EFI, 2014, Fraunhofer ISI, 2014). One trigger is the massive and unanticipated expansion of solar PV installations under EEG provisions. With PV panel prices down by more than 60 per cent over the last six years, the expansion of capacity has exceeded government targets by a factor of two. Against this backdrop, political negotiations are ongoing in the new coalition government on a proposal to rein in future capacity expansion. Specifically, the proposal envisages the introduction of ceilings for future capacity growth, strong reductions of future FiT rates and an ambitious degression scale. In the following sections, we aim to contribute to a rational basis for decision making on the future of the German EEG, and the system of FiTs in particular, by contrasting cost estimates with quantitative indicators for benefits of solar PV and wind energy support. 


\subsection{Methodological approach}

\subsubsection{Cost assessment}

The German feed-in tariff (FiT) approach has become an "export success story" in itself, and, to date, has been replicated in essence (with variations in detail) in more than 50 countries worldwide. It continues to be widely recognized as a benchmark for effective policy design in support of renewable energy expansion. Therefore-and also in view of limited annualized data availability for the volume and terms of renewable energy loans, as well as R\&D expenditures-this paper will focus entirely on seeking to assess the cost-effectiveness of this policy instrument.

To this aim, we present estimates on the differential cost of the FiT, that is, the difference between FiT rates and the electricity market price. It is important to note that this estimate includes distributional effects, and is thus higher than the macroeconomic cost of wind and solar PV energy production induced by the FiT. This differentiation is essential, although not always made explicit in the literature. The additional macroeconomic costs themselves arise from the fact that electricity production from most renewable sources is still more expensive than from conventional sources. These costs can be measured as the difference between the levelized cost of electricity (LCOE) generated from renewable sources and the LCOE of nonrenewable sources. ${ }^{1}$ If a FiT is to induce investments in renewable energy, it needs to cover these costs and a reasonable markup as compensation for the added risks of such investments. The markup, however, does not add to macroeconomic costs. It is rather a redistribution of funds from electricity consumers to producers of renewable energy. The EEG surcharge thus includes an additional component, which cannot be counted as a macroeconomic cost. It may, however, have strong distributive effects. In the case of Germany, these are reinforced by the exemptions granted to energy intensive enterprises, which raise the burden on the remaining consumer groups.

The shares of the FiT-related differential costs attributable to wind and solar PV are calculated in accordance with the following methodology (BDEW, 2013):

- Based on the average annual FiT paid (in $€ \mathrm{ct} / \mathrm{kWh}$ ) for each energy source and the volume of electricity fed into the grid, the total amount of paid-out FiT is calculated and compared with the prevailing electricity market prices, thus arriving at the differential costs.

- A weighting scheme for individual energy sources is applied with a view to addressing fluctuating market prices and temporal feed-in patterns (e.g., peak feedin of solar PV electricity around midday, corresponding with peak demand patterns

\footnotetext{
${ }^{1}$ Levelized Cost of Electricity (LCOE) is calculated on the basis of the total expenses (investment, operation, maintenance, replacement, insurance etc.) of a project over its entire life span. These are discounted to the same reference point and divided by the present values of the electricity output. For a critique of various concepts of LCOE and grid parity see Bazilian, et al, 2013.
} 
and thus high electricity spot market prices, in contrast to more irregular wind feedin times). ${ }^{2}$

- The "market premium" option introduced in the 2012 EEG amendment is reflected in the calculation.

\subsubsection{Benefits assessment}

After assessing the cost, we proceed to identifying the positive impact of support policies. What have been the benefits generated in terms of building up new competitive industries, fostering innovation, creating employment, and contributing to fighting climate change? Only after having assessed both the costs and benefits of policy interventions in favour of renewables will it be possible to meaningfully assess the question of cost-effectiveness.

We rely on two indicators to assess the development of Germany's competitiveness in wind and solar PV: world market share, defined as the share a country has in world exports for a given product, and revealed comparative advantage (RCA ${ }^{3}$. The RCA is one of the most commonly used competitiveness indicators. It compares the export-import ratio of one product to that of all products for the same country. The values of RCA can vary hugely and theoretically reach infinity. In order to be able to present the values better in graphs, we "normalize" them, using the tanh function (tangens hyperbolicus), multiplying the number by 100 , and using the In (logarithmic) function. In this approach, positive numbers indicate a competitive advantage (see also Eichhammer \& Walz, 2009, with data coverage up to 2008).

In terms of data sources, we rely on the United Nations Commodity Trade Statistics Database (UNCOMTRADE, 2013). ${ }^{4}$ The product nomenclature used originates from the Harmonized System (HS 1996), which is available at the 6-digit level. Specifically, for wind energy and solar PV, it offers the following two product groups:

- 850231: "Other generating sets-wind powered" (referred to below as wind converters).

- 854140: "Photosensitive semiconductor devices, including photovoltaic cells whether or not assembled in modules or made up into panels; light emitting diodes" (referred to below as solar PV).

Two caveats are in order:

First, it needs to be understood that the RCA approach of measuring competitiveness cannot discriminate between specialization patterns rooted in structural economic determinants (factor endowments, productivity etc.) and those caused by trade policy interventions. For

\footnotetext{
${ }^{2}$ The weighting factors applied have changed over time. In 2013, the factor for solar PV was 98 per cent while for wind energy it was 89 per cent.

${ }^{3}$ This differs from Balassa's original concept of revealed comparative advantage, which is solely based on export performance.

${ }^{4}$ Available at: www.wits.worldbank.org/WITS/WITS/Restricted/Login.aspx
} 
instance, a country's temporary recourse to import restrictions or export dumping practices would translate immediately into an improved RCA value. Second, in a few cases annual fluctuations of country-specific export and import data are of such an immense magnitude that doubts arise as to their accuracy. However, UNCOMTRADE data cannot be verified here and must be assumed as being correct.

The measurement of innovation dynamics is notoriously difficult. In the absence of sufficient company-level data on R\&D investments, international patent data can be a useful proxy indicator. However, evidence needs to be treated with care. Results will differ in accordance with the database applied, the country in which a patent has been filed, the reliance on either patent applications or patents granted as well as the inventor's or applicant's home country. Also, the significant time required for processing a patent registration and the incidence of cross-sectoral patent use (e.g., electronics patents applied in solar PV; machinery and automotive patents applied for wind turbine gearboxes) would ideally need to be considered. Lastly, patents can only indicate the aspects of the innovation process which are based on patented knowledge (Fraunhofer ISI, 2014). They thus provide only part of the picture.

The results presented in Figures 7 and 8 are based on the OECD Patent Database (as updated in January 2013 with data up to 2010, OECD, 2013). They cover patent applications (not patents granted), which are generally considered to be a better indicator for innovation dynamics. The relative patent shares (RPS) have been calculated by using the same methodology as applied earlier for calculating relative world trade shares. RPS thus compares, for a given country, the world share for a patent of one specific technology with the world patent share across all technologies.

The solar and wind technology sectors have grown into significant providers of employment in the German economy. While no data are available on the number of net jobs created, there are reliable data on gross employment creation both directly through capacity investment and indirectly through maintenance, operation and other support activities.

To assess the environmental benefits of the FiT, we rely on directly avoided carbon dioxide $\left(\mathrm{CO}_{2}\right)$ emissions for which consistent time series data are available. Data in Table 3 are based on applying specific substitution factors for wind energy and solar PV, respectively. This is relevant in view of the fact that the emission intensities of coal, lignite and natural gas differ substantially. More specifically, the following substitution patterns are assumed:

- For wind energy: coal 80 per cent, natural gas 17 per cent and lignite 3 per cent

- For solar PV: coal 75 per cent, natural gas 22 per cent and lignite 3 per cent 


\section{Results and discussion}

\subsection{Costing the Feed-in tariff}

Figures 1 and 2 present the shares of the FiT-related differential costs attributable to wind and solar PV, respectively.

Figure 1 Annual differential costs in million $€$ under EEG-FiT (2005-2013) ${ }^{5}$

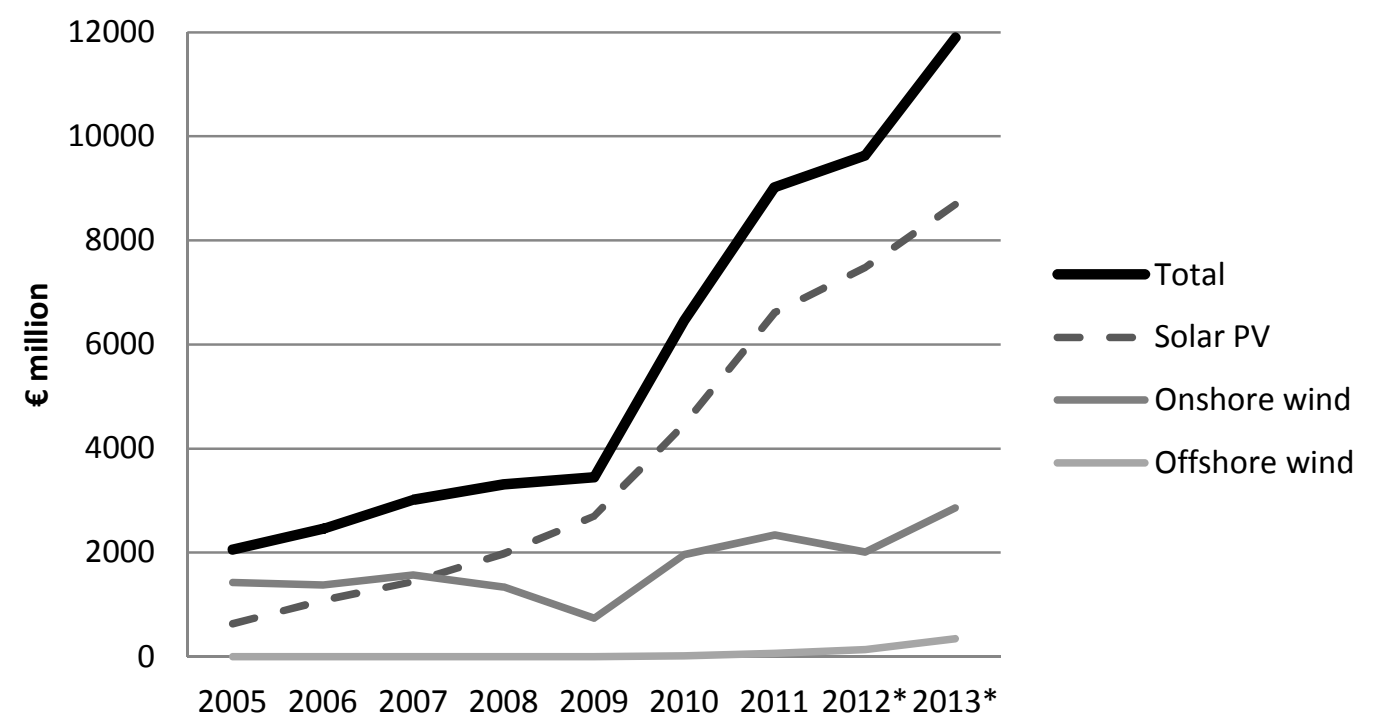

*Projection

Source: Data from BDEW, 2013, pp. 37-38.

Figure 2 Annual differential costs in €ct/kWh under EEG-FiT (2005-2013)

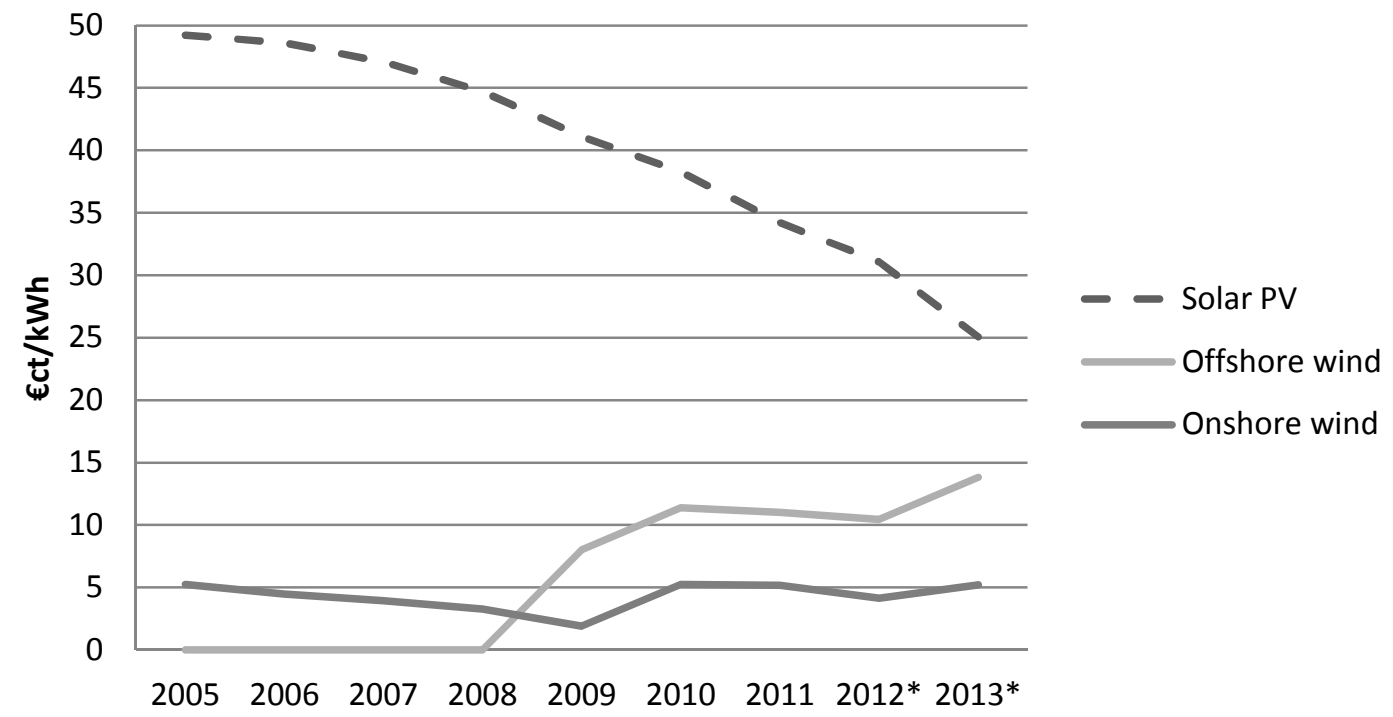

*Projection

Source: Data from BDEW, 2013, pp. 37-38.

${ }^{5}$ Unless explicitly stated otherwise, all tables and figures refer to the case of Germany. 
From Figure 1, it can be seen that the combined projected differential costs for wind energy and solar PV promotion amount to close to $€ 12$ billion in 2013-almost double the amount of 2010. Moreover, Figure 1 clearly shows a pattern of a relative increase in the weight of solar PV within the total differential cost scenario: between 2005 and 2013, the ratio of total solar PV subsidies to total onshore wind subsidies (in $€$ million) rose from 0.4 to 3.0, i.e., from less than half to three times as much. This coincided with a narrowing of the same ratio in terms of $€ \mathrm{ct} / \mathrm{kWh}$, as shown in Figure 2: in 2005, the average feed-in differential tariff for solar PV was 9.4 times higher than for onshore wind; in 2013 this factor was down to 4.8the obvious explanation being the FiT reductions triggered by the phenomenal cost decreases and subsequent growth of solar PV electricity generation. While the latter grew by a factor of 27, wind-generated electricity just doubled in volume from 2005 to 2013.

However, a holistic look at the composition of electricity prices is necessary with a view to putting the EEG-surcharge in perspective. Electricity prices basically result from the costs of generation, transmission and distribution; various state taxes and levies; and finally the EEGsurcharge. In 2013, the latter accounted for 22 per cent of electricity prices for households and 35 per cent for industrial consumers. In 2005, the shares were 5 per cent and 7 per cent, respectively. Thus, while contributing between one fifth and one third to total prices, the EEG surcharge has increased rapidly in recent years to become a pronounced cost factor.

In the context of this growing relative weight, the distributional impact of the EEG-surcharge has become a controversial subject. In 2013, the EEG apportionment for electricity consumers, i.e., the rise in their electricity price attributable to the FiT, amounted to 5.3 $€ c t / k W h$. Private households (with an electricity consumption share of roughly one quarter) have to bear 35 per cent of the surcharge while the industrial sector (with a consumption share of almost 50 percent) accounts for only 30 percent of the surcharge-largely a result of exemptions for energy-intensive industries. However, the financial burden to be borne by households is easily overestimated. A recent study concludes that in a scenario of a further $1.3 € c t / k W h$ increase of the electricity surcharge by 2015 , additional expenditures would amount to just 0.1 per cent of the average disposable household income, although with a slightly regressive effect (Lehr \& Drosdowski, 2013).

Furthermore, the subsidies provided by the FiT are not higher than the subsidies paid per unit of electricity generated from coal and nuclear power. In essence, a visibility bias is at work here. While the subsidies for renewables appear explicitly as electricity surcharge on the power bill of end consumers, subsidies for conventional energy sources are embedded in state budgets. This applies not only to tax incentives, but more importantly, to the direct provision of infrastructure (grid construction and expansion) and even the costly search and management process of nuclear waste disposal sites. 


\subsection{Assessing the benefits of the energy transition 3.2.1. Competitiveness}

The notion of competitiveness is one of the most fundamental concepts in economics. However, exactly how to define and measure competitiveness and how to delineate its meaningful remit has remained highly controversial, in particular when moving up from competing firms to competing locations, sectors or entire economies and, for that matter, nations. Famously, Krugman (1994) went as far as branding competitiveness as a "dangerous obsession" of policy-makers. This may indeed apply to much of the popular debate and its oversimplifications, yet it does remain a valid concern-economically and politically-to ascertain how goods produced in a country can stand the test of international market acceptance and how they fare in relation to the same goods produced elsewhere. This section therefore reviews the competitiveness of the German wind energy and solar PV industries.

\section{Wind converter competitiveness}

Figures 3 and 4 send the resounding message of the build-up over time of a highly competitive German wind converter industry. Between 2004 and 2012, its export share in the global market surged from 10 to almost 50 per cent - thus assuming the position of leading export country. Background data point to a staggering export growth of 65 per cent from 2011 to 2012 . The low world market share before 2005 are explained by the fact that in those years Germany represented a lead market for wind energy - accounting for 45 per cent of wind converter installations worldwide in 2002 (down to 7 per cent in 2005). The pioneering FiT introduction had created such a strong domestic market pull that early export efforts were effectively stifled. A similar pattern can be observed for the revealed comparative advantage: its values increased sharply in 2005 and kept growing in the period up to 2012. In terms of comparator countries, the recent growth in China's and Spain's market shares is to be noted, as is the rapid and consistent loss of market shares by Denmark. 
Figure 3 Wind converters: world market shares (percentage) by country 2000-2012
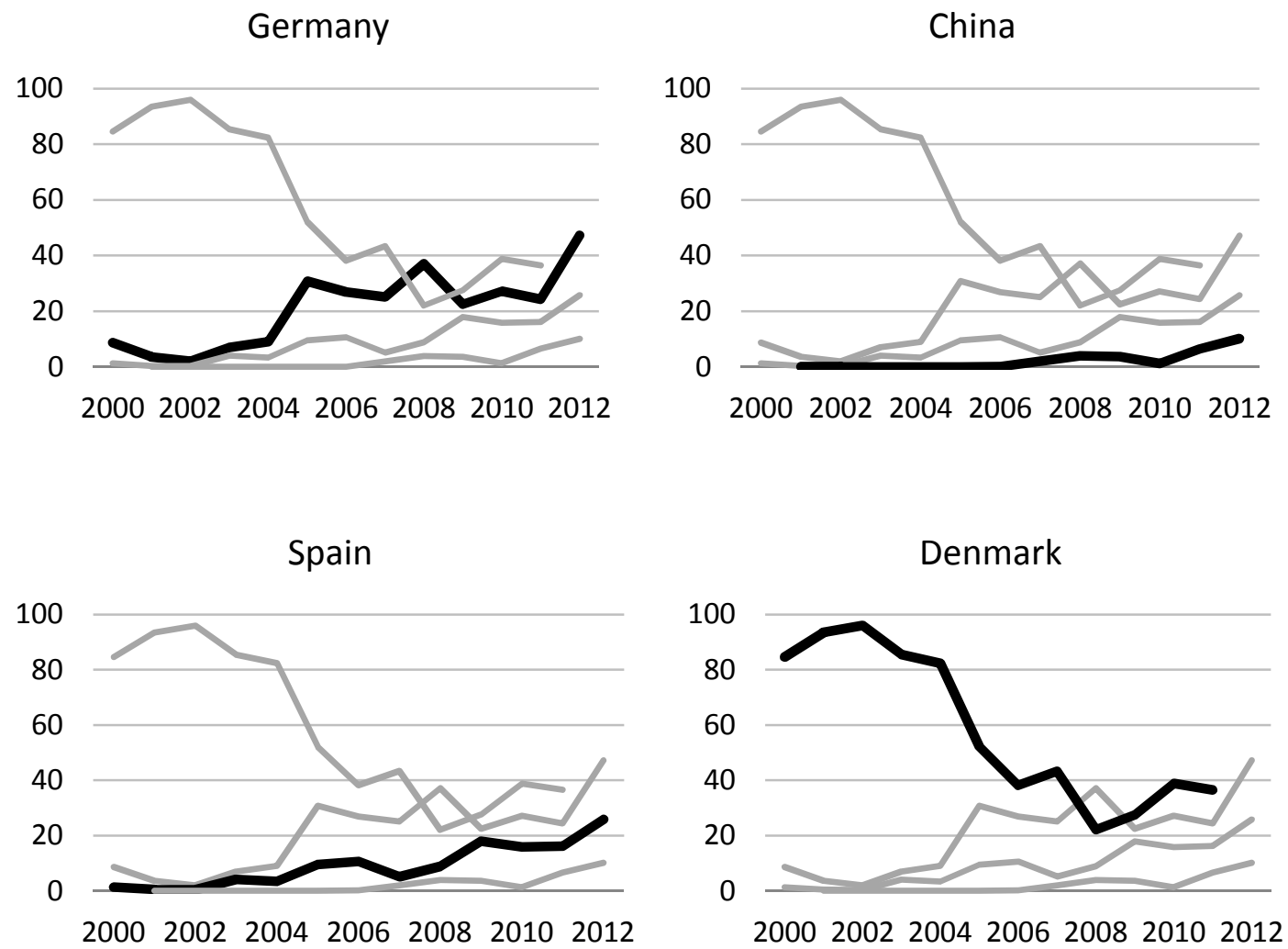

Source: Authors' calculations based on UNCOMTRADE.

Note: The four diagrams are identical, differing only in the country highlighted.

Figure 4 Wind converters: Germany's Revealed Competitive Advantage 2000-2012

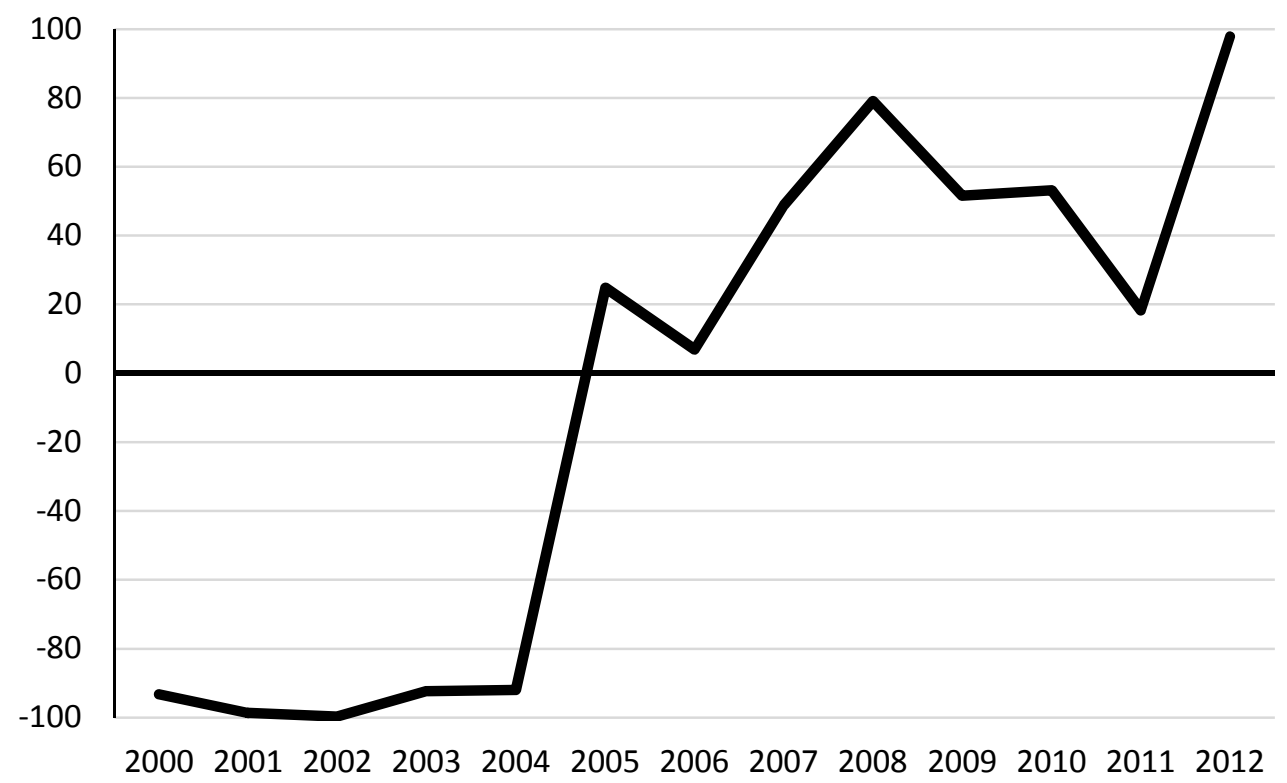

Source: Authors' calculations based on UNCOMTRADE. 
Beyond the aggregate data presented in the charts, industry analysts underline the particularly strong competitive position of German companies when it comes to offshore turbines (and offshore wind parks in general), as well as large-scale onshore turbines above $5 \mathrm{MW}$ capacity. A particular driver of competitive strength originates from a classical technology cluster constellation in the four Northern states of Lower Saxony, SchleswigHolstein, Bremen and Hamburg. ${ }^{6}$ This so-called North Western Region Wind Power Cluster has grown into a densely interconnected web of more than 300 partners-comprising globally leading turbine manufacturers, specialized component suppliers, wind park operators, local governments and cutting-edge research institutions. The cluster boasts some of the industry's major innovations (e.g., the development of the $5 \mathrm{MW}$ offshore urbine and the offshore test site Alpha Ventus).

At the same time, the wind cluster also owes some of its success to the long-standing track record of Germany's engineering, machinery and power sectors in general. Without the foundation of highly advanced manufacturing capabilities and skills across a whole range of industries, the German wind energy sector would not have been able to achieve global technological leadership. Arguably, the North Western wind cluster represents an internationally unique level of sophistication and comprehensiveness, with business players along the entire value chain exhibiting a high intensity of interactions based on shared ambitions and quality standards. The cluster represents a genuine public-private partnership and is co-funded by state resources and business membership fees.

\section{Solar PV competitiveness}

The global solar PV market, even more so than other renewable energy markets, is a highly political market shaped by trade patterns that are subject to significant government interventions. The recent EU-China trade dispute around subsidized solar panel exports and alleged dumping practices bears testimony to this feature. Hence, analyzing revealed comparative advantages must be seen with this caveat in mind.

Figures 5 and 6 clearly demonstrate a relatively lower international competitiveness of the German solar PV industry compared to the German wind energy industry. A temporary increase in the world market share up to 2008 (15 per cent) could not be sustained: in 2012, this share fell back to its pre-2005 level of below 10 per cent. Background data show that German exports of solar PV were almost cut in half between 2010 (US\$8.1 million) and 2012 (US\$4.5 million). Similarly, we can witness a consistent revealed comparative disadvantage over the entire period from 2000 to 2012. In terms of comparator countries, the spectacular rise of China stands out. By 2010, the country was in the leading position in both indicators presented here.

\footnotetext{
${ }^{6}$ For details see www.windpowercluster.com and the case study by Boeckle et al., 2010.
} 
Germany

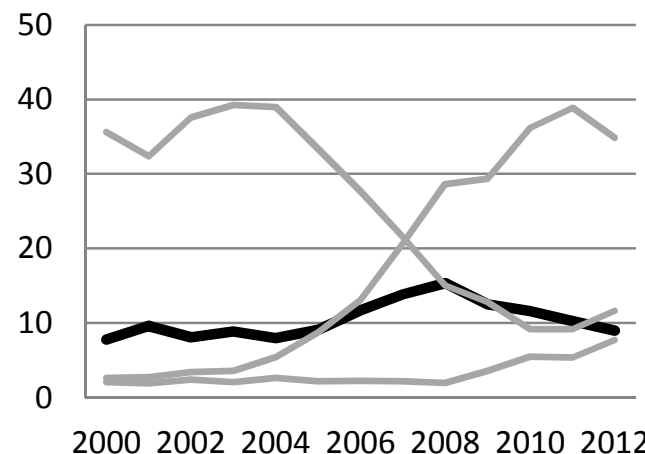

Japan

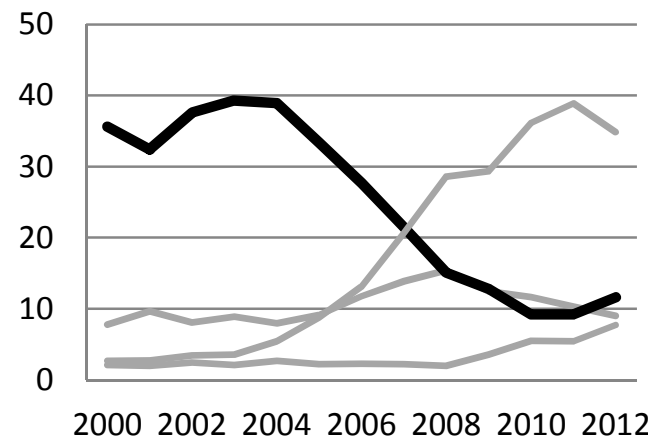

China

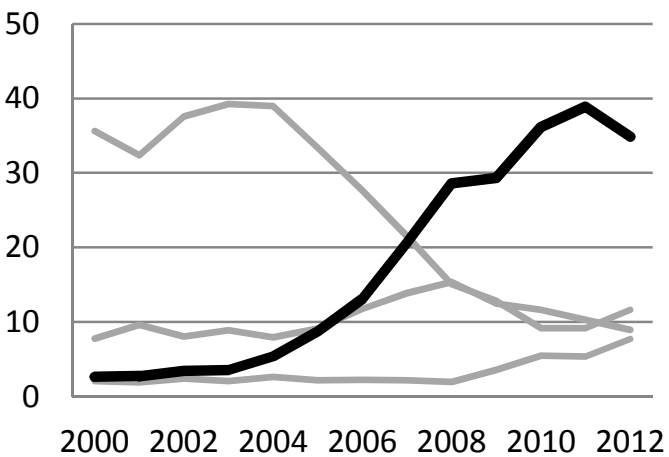

Korea, Rep.

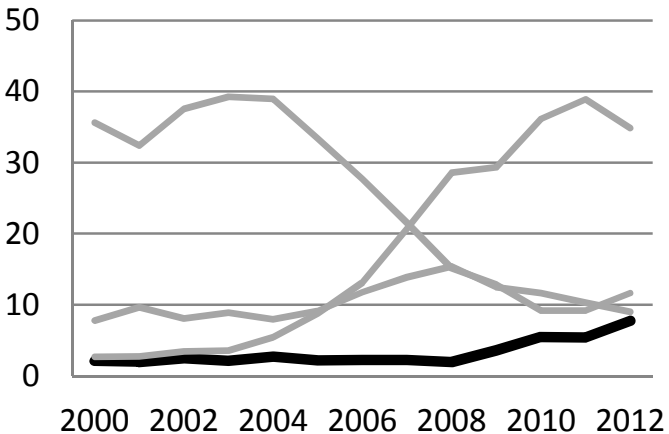

Source: Authors' calculations based on UNCOMTRADE.

Note: The four diagrams are identical, differing only in the country highlighted.

Figure 6 Solar PV: Revealed Competitive Advantage by country 2000-2012

Germany

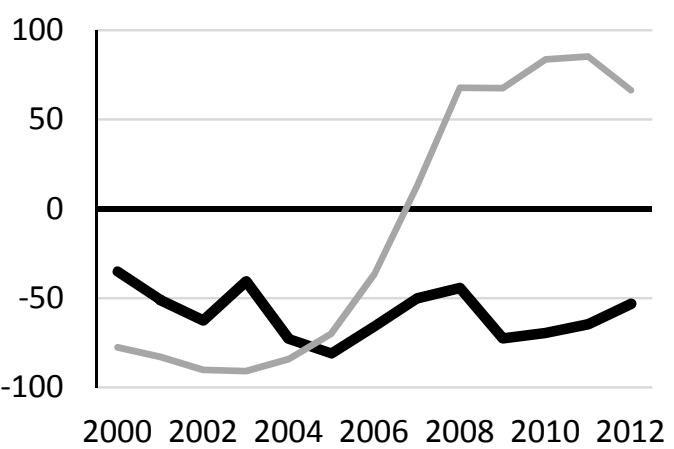

China

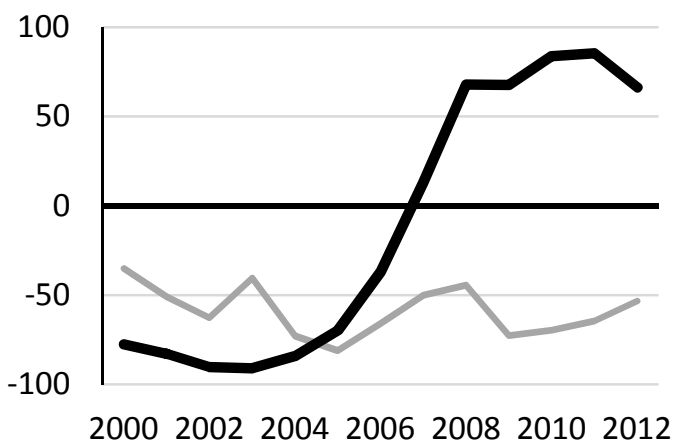

Source: Authors' calculations based on UNCOMTRADE.

Note: The two diagrams are identical, differing only in the country highlighted.

Beyond the aggregate data presented in the charts, the strong competitive position of German PV system component manufacturers and equipment suppliers must be emphasized. Data for 2011 show that the share held by German firms in the global market for specialized PV equipment was as high as 50 per cent, while the market share of PV 
inverters (converting the direct PV cell current into alternating grid current) stood at 35 per cent (GTAl, 2013, fact sheets).

\subsubsection{Technological Innovation}

A positive value in Figures 7 and 8 indicates that the technology under consideration has a superior patent (innovation) position compared to the entire technology portfolio of a country.

Figure 7 Wind Energy: Relative Patent Shares by country, 2000-2010
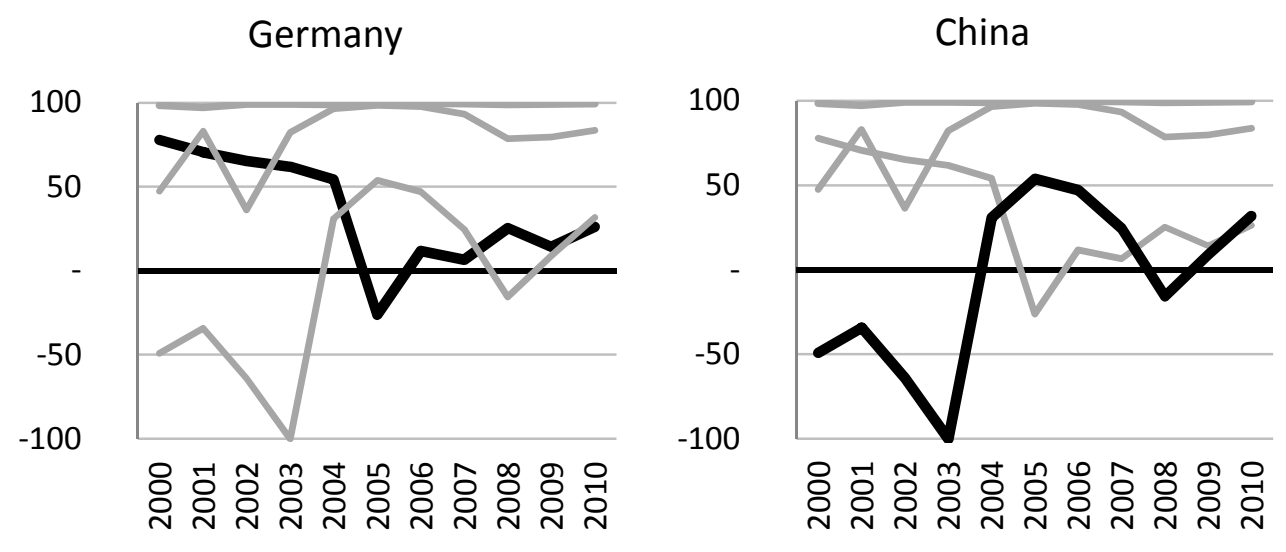

Denmark

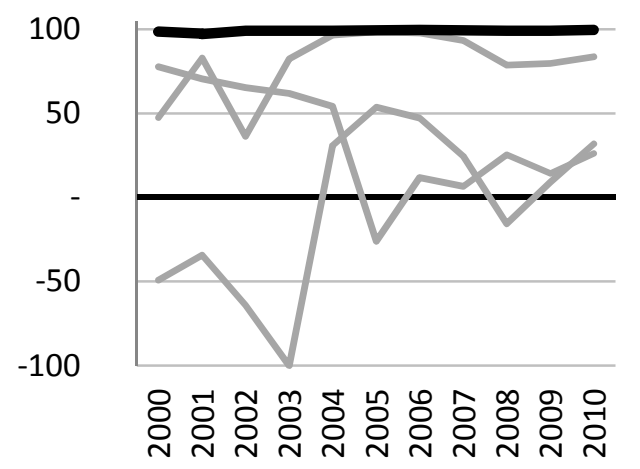

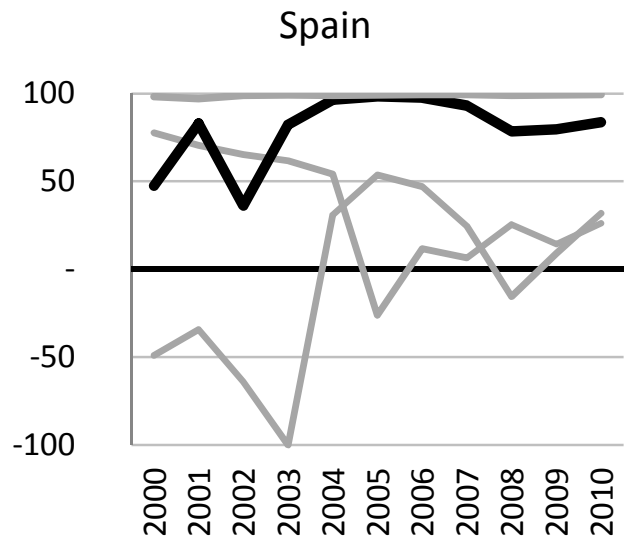

Source: Authors' calculations based on OECD Patent Database.

Note: The four diagrams are identical, differing only in the country highlighted. 
Figure 8 Solar PV: Relative Patent Shares by country 2000-2010

Germany

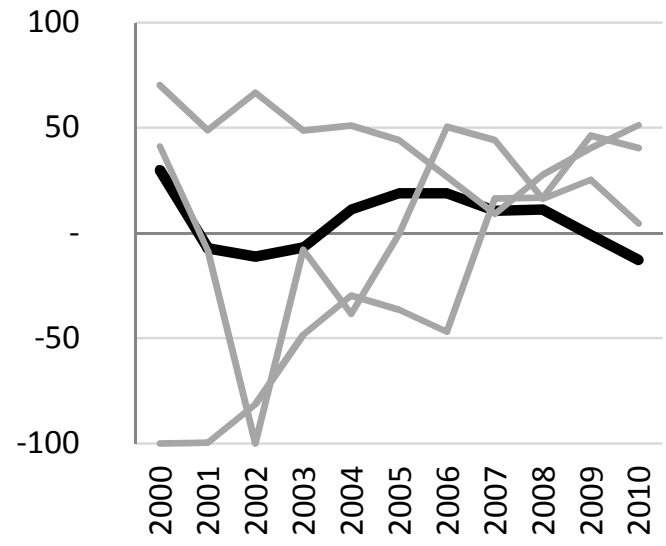

Spain

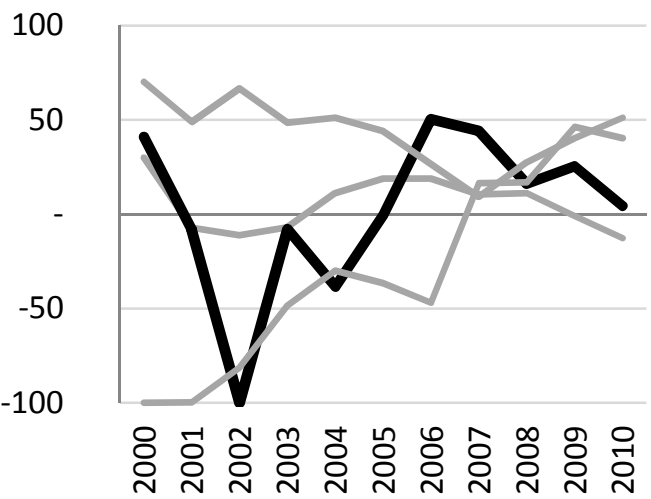

Korea, Rep.

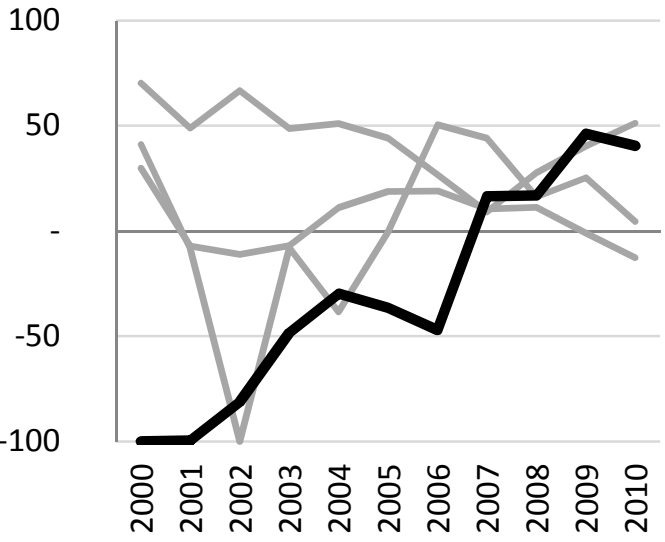

Japan

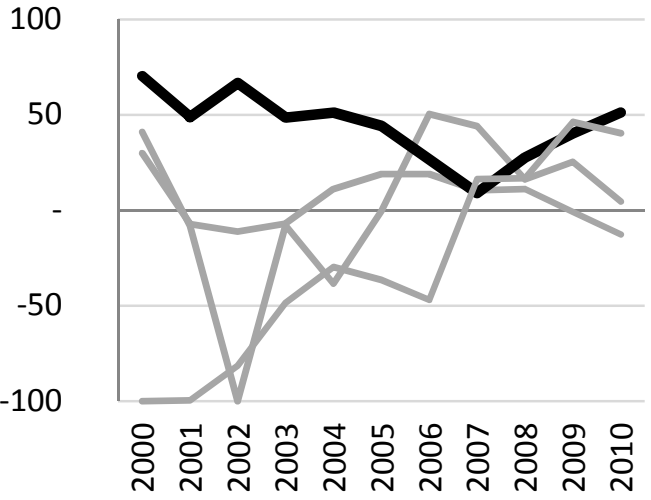

Source: Authors' calculations based on OECD Patent Database.

Note: The four diagrams are identical, differing only in the country highlighted.

It emerges that in the case of Germany, wind energy-after a trend reversal in 2005-has consistently achieved a positive RPS (value of +26 in 2010), while the opposite applies for solar PV. From a moderately positive RPS up to 2006, the trend has been downwards resulting in negative RPS as of 2009 (with a value of -13 in 2010). Background data show that between 2005 and 2010, the absolute number of German wind energy patents more than tripled; the number of solar PV patents increased by one quarter.

These results are corroborated by a similar analysis undertaken for 2009 based on European Patent Office (EPO) data (Bointner, 2012) in which the gap between a positive RPS value for wind technology and a negative RPS value for solar PV technology is even more pronounced. They are further substantiated by a recent broader cross-country analysis of green technology patents based on World Intellectual Property Organization's (WIPO) classification (Bierenbaum et al., 2012), which led to the following results (for the 1990-2010 period): 
- While trailing behind the U.S. and Japan in terms of the absolute number of "green" patents ${ }^{7}$ granted, Germany exhibits the highest per capita green patent intensity of all countries worldwide.

- In wind energy technology, Germany is comparatively stronger as an innovator (measured as share of cumulative global wind patents) than as an adopter (share of installed global wind power capacity) although the difference, with 21 per cent and 14 per cent respectively, is relatively small.

- In solar PV technology, Germany is comparatively stronger as an adopter than as an innovator, with a 44 per cent share of installed global capacity and only 12 per cent share of global cumulative patents.

In general, there seems to be a closer alignment between innovation and deployment trends in the case of wind energy, while for solar PV, innovation and deployment hubs may be decoupled as PV technology is more easily transposable to countries with the most conducive incentives structure for large-scale deployment (Lee et al., 2009). From the same study, it emerges that several German wind energy companies are among the top 20 patent holders (Enercon ${ }^{8}$ indeed is number 1 , followed by Siemens at number 7 ) whereas in the case of solar PV patents only Siemens figures at number 20.

\subsubsection{Employment Creation}

Of the almost 380,000 total jobs created by renewable energies in 2012 (for the first time, down from the previous year), more than half ( 54 per cent) were accounted for by solar PV and wind energy alone (Table 1). Based on the two sources below Table 1, the following structural features stand out:

- The share of new jobs attributable to the Renewable Energy Sources Act (EEG) has grown over time: from 61 per cent in 2004 to 71 per cent in 2012. More specifically, of the 268,000 jobs created through the EEG in 2012, wind energy accounted for 117,900 and solar PV for 87,800 with the remainder originating from biomass plants.

- While the majority of jobs stem from investments into solar and wind installations, the share of jobs related to maintenance and operation services is growing. This applies in particular to onshore wind, where the share of maintenance and operations jobs is as high as 16 per cent. For solar PV, the same share stands at 10 per cent. Despite the 2012 slump in new solar installations, maintenance and operation jobs kept growing.

\footnotetext{
${ }^{7}$ According to WIPO's Green Inventory, "green patents" cover alternative energy production patents in 13 sectors: solar, wind, geothermal, biofuel, biomass, fuel cell, hydro, synthetic gas, integrated gasification combined cycle, man-made waste, mechanical power from muscle energy, natural heat and waste heat.

${ }^{8}$ Enercon patents are registered under the name of Aloys Wobben, who founded the company in 1984 and has remained its owner to date.
} 
- Export markets play an essential role in employment creation. For all renewables, in 2012 the domestic market generated 59 per cent of investmentrelated jobs, with export markets accounting for 41 per cent. In view of the above-average export ratio of electricity-generating technologies, export-driven employment must be even higher for wind energy and solar PV.

- The regional distribution of employment is more dispersed than often assumed. While there is a basic pattern of more wind installations in the Northern and Eastern coastal regions and a higher solar PV intensity in Southern federal states, component-driven employment is often located in the traditional industrial centres. At the same time, an important inequality-reducing impact is noticeable: In those Eastern federal states suffering from the highest unemployment ratios nationwide (with the exception of city states), the relative importance of solar and wind employment is most pronounced. Specifically, this applies to Mecklenburg-Western Pomerania, Saxony-Anhalt and Brandenburg with unemployment rates (June 2013) of 10.8 per cent, 10.7 per cent and 9.5 per cent, respectively.

- In terms of the skill profile of the labour force (see Table 2), employment in both the solar PV and wind energy industry is very much in line with the comparative advantage of a sophisticated labour market in a high-tech economy like Germany's. While there is a negligible share of unskilled labour, in both the wind and particularly the solar PV industry the share of university-degree staff is around three times as high as the national industry average. 
Table 1 Employment created by wind energy and solar PV, 2010-2012

\begin{tabular}{|c|c|c|c|c|c|c|}
\hline & \multicolumn{2}{|c|}{ Investment-related jobs } & \multicolumn{2}{|c|}{$\begin{array}{l}\text { Jobs in maintenance } \\
\text { and operation }\end{array}$} & \multicolumn{2}{|c|}{ Total jobs } \\
\hline Year & 2011 & 2012 & 2011 & 2012 & 2011 & 2012 \\
\hline Wind & 82,600 & 98,600 & 18,500 & 19,300 & 101,100 & 117,900 \\
\hline - onshore & & 81,300 & & 18,600 & & 99,900 \\
\hline - offshore & & 17,300 & & 700 & & 18,000 \\
\hline Solar PV & 103,300 & 78,900 & 7,600 & 8,900 & 110,900 & 87,800 \\
\hline $\begin{array}{l}\text { Total renewable } \\
\text { energies }\end{array}$ & 242,000 & 227,100 & 75,800 & 80,700 & $381,600^{a}$ & $377,800^{a}$ \\
\hline $\begin{array}{l}\text { Total share of } \\
\text { wind (per cent) }\end{array}$ & 34 & 43 & 24 & 24 & 26 & 31 \\
\hline $\begin{array}{l}\text { Total share of solar } \\
\text { PV (per cent) }\end{array}$ & 43 & 35 & 10 & 11 & 29 & 23 \\
\hline \multicolumn{7}{|c|}{$\begin{array}{l}\text { a Includes also jobs created by fuel supply activities (biogas, biomass, biofuel), as well as related } \\
\text { jobs in public institutions (R\&D, administration). } \\
\text { Sources: Based on data in Federal Ministry for the Environment, 2012; O'Sullivan, Edler, Bickel, } \\
\text { Lehr, Peter, \& Sakowski, } 2013 .\end{array}$} \\
\hline
\end{tabular}

Table 2 Skill profile of employment in the wind energy and solar PV sector (survey-based; percentage shares)

\begin{tabular}{|lccc|}
\hline & $\begin{array}{c}\text { No vocational } \\
\text { training }\end{array}$ & $\begin{array}{c}\text { Completed } \\
\text { vocational training }\end{array}$ & University degree \\
\hline Wind energy & 0.9 & 79.9 & 27.1 \\
\hline Solar PV & 5.8 & 81.7 & 34.7 \\
\hline Total industry & 15.0 & 69.5 & 9.9 \\
\hline Source: Federal Ministry for the Environment (BMU), 2012. & \\
\hline
\end{tabular}

\subsubsection{Environmental Benefits from Avoided Emissions}

As emphasized in Section 2, from the outset one of main drivers of renewable energy promotion in Germany has been the political commitment to achieving ambitious goals of reducing greenhouse gas emissions in the fight against climate change, as well as reaching environmental objectives in terms of reducing various pollutants. Hence, the question of exactly what level of avoided emissions can be attributed to the growing deployment of wind energy and solar PV is of particular importance. 
In Table 3, we take a look at directly avoided carbon dioxide $\left(\mathrm{CO}_{2}\right)$ emissions for which consistent time series data are available. It emerges that between 2005 and 2012 the amount of avoided $\mathrm{CO}_{2}$ emissions has more than doubled from 23.8 million tonnes to 56.5 million tonnes. The contribution of wind energy and solar PV to reducing Germany's carbon footprint thus is of significance at the broader national level: In 2012, both sectors combined avoided $\mathrm{CO}_{2}$ emissions amounting to 6.9 per cent of total $\mathrm{CO}_{2}$ emissions, or 17.8 per cent of $\mathrm{CO}_{2}$ emissions caused by electricity generation. When considering the entire 2005 to 2012 period, more than one tenth (11.3 per cent) of electricity-related $\mathrm{CO}_{2}$ emissions could be prevented.

Table 3 Directly avoided $\mathrm{CO}_{2}$ emissions from wind energy and solar PV, 2005 to 2012 (in 1,000 tonnes) ${ }^{a}$

\begin{tabular}{|c|c|c|c|c|c|}
\hline Year & Wind & Solar PV & $\begin{array}{l}\text { Wind plus } \\
\text { solar PV }\end{array}$ & $\begin{array}{l}\text { Share of total } \\
\mathrm{CO}_{2} \text { emissions } \\
\text { (per cent) }\end{array}$ & $\begin{array}{l}\text { Share of } \mathrm{CO}_{2} \\
\text { emissions from } \\
\text { electricity generation } \\
\text { (per cent) }\end{array}$ \\
\hline 2005 & 23,227 & 616 & 23,843 & 3.3 & 7.4 \\
\hline 2006 & 24,038 & 1,341 & 25,379 & 2.9 & 7.7 \\
\hline 2007 & 30,367 & 1,818 & 32,185 & 3.8 & 9.5 \\
\hline 2008 & 28,989 & 2,978 & 31,967 & 3.8 & 10.0 \\
\hline 2009 & 28,211 & 4,435 & 32,646 & 4.2 & 11.2 \\
\hline 2010 & 27,244 & 7,792 & 35,036 & 4.2 & 11.5 \\
\hline 2011 & 35,239 & 12,848 & 48,087 & 6.0 & 15.8 \\
\hline $2012^{b}$ & 35,489 & 20,998 & 56,487 & 6.9 & 17.8 \\
\hline \multicolumn{6}{|c|}{$\begin{array}{l}{ }^{a} \text { According to the sources given below, wind avoids } 726 \mathrm{gCO}_{2} / \mathrm{kWh} \text { and solar } \mathrm{PV} 613 \\
\mathrm{gCO}_{2} / \mathrm{kWh} \text {. } \\
{ }^{\mathrm{b}} \text { Total } \mathrm{CO}_{2} \text { emissions and } \mathrm{CO}_{2} \text { emissions from electricity generation are estimates. } \\
\text { Sources: Compiled and calculated from AGEE-Stat, 2012; Umweltbundesamt, 2013a; } \\
\text { Umweltbundesamt, 2013b. }\end{array}$} \\
\hline
\end{tabular}

Numerous life cycle assessments of the ecological balance sheet of alternative energy sources have been undertaken in recent years. The overall result of a comparatively much smaller carbon and ecological footprint of wind energy and solar PV than, for example, coalbased electricity, is unequivocal. Relevant data for Germany lead to the conclusion that in terms of $\mathrm{CO}_{2}$, coal-based electricity generates around 100 times more emissions per unit than wind energy and 10 to 20 times more than solar PV. 
In assessing the ecological impact of the FiT, it must be noted that greenhouse gas emissions in the European context are traded under the European Emissions Trading Scheme (EU ETS). Any FiT-induced lowering of $\mathrm{CO}_{2}$ emissions reduces demand for certificates, cuts their price, and thus discourages investments in emission reductions elsewhere. On the other hand, the lower price of certificates opens political space for tighter ETS caps without threatening the competitiveness of companies. Without such tighter caps, however, the parallel operation of FiT and ETS will crowd out the former's emission reduction benefits-at least for those emissions traded under the ETS.

\subsection{Contrasting Wind and Solar PV}

In Figure 9, a stylized summary of the main quantitative results of Section 3 is presented, complemented by the EEG differential costs as proxy for the additional cost of wind and solar. While not amounting to an objective assessment of each sector, the comparison between wind energy and solar PV would indicate that the wind energy sector is leading in all performance dimensions: employment creation, competitiveness, technological innovation and avoided $\mathrm{CO}_{2}$ emissions-and does so with lower subsidy levels. 
Figure 9 Stylized profile of wind energy and solar PV by performance dimension (latest available years)

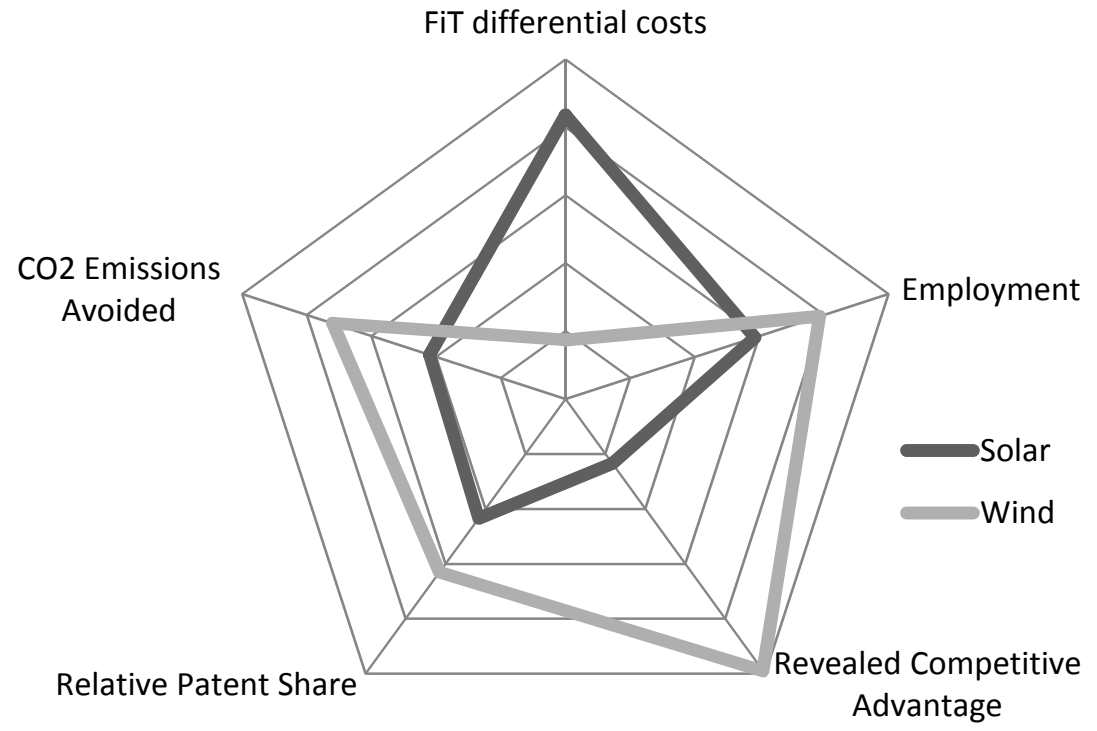

Source: Based on Tables 1 and 3, and Figures 2, 4, and 6-8 in this paper.

Note: An appropriate scaling was introduced for each performance dimension. Specifically, the following values were defined as 100 per cent:

- FiT differential costs: $30 € \mathrm{ct} / \mathrm{kWh}$

- Employment: 150,000 jobs

- RCA: 200 (based on -100 to +100 range)

- RPS: 200 (based on -100 to +100 range)

- $\mathrm{CO}_{2}$ emissions avoided: 50 million tonnes

Also in terms of medium-term projections of the levelized cost of electricity (LCOE) for wind energy and solar PV in Germany (Fraunhofer ISE, 2012), onshore wind plants are considered to remain the most cost-effective renewable energy technology. Currently at $8 € c t / k W h$ (at 2000 full-load hours per year), the LCOE for onshore wind energy is forecast to marginally decrease further to $7 € \mathrm{ct} / \mathrm{kWh}$ in 2030. Solar PV systems are expected to remain more costly, however, they are coupled with much faster cost decreases due to a steeper technological learning curve. Overall, this would lead to onshore wind plants becoming costcompetitive with a conventional (fossil plus nuclear) electricity mix by 2017 , while the same would apply for ground-mounted solar PV systems by 2022.

The above stylized comparison of solar PV and wind energy has a number of broader industrial policy implications, which will be discussed in Section 4. 


\section{Conclusions and policy implications}

While green industrial policy in Germany targets many sectors (for example resourceefficient environmental technologies, waste management, biofuels production or electromobility), the energy transition (Energiewende), with its focus on renewable energy sources is certainly the most prominent national project. It places Germany among the most ambitious countries worldwide in the promotion of a transition to sustainable energy. However, public debate in Germany about the Energiewende in general and its different features in particular is highly politicized, and often driven by ideology or vested interests. This paper has sought to provide a balanced assessment drawing on the best available evidence and quantifying explicitly what costs and benefits are excluded or included.

Germany has a variety of policies in place to support the Energiewende. Among them are mechanisms targeting all stages of renewable energy technology development from basic research to deployment. The system of feed-in tariffs (FiT) is the core element of Germany's policy package, and as such deserves closer analysis. In the energy policy community, there is widespread agreement that the FiT mechanism in general, and its application in Germany in particular, has proven to be an exceedingly effective policy instrument for pushing renewable energies into the market (Haas et al., 2011; Held et al., 2006; Matschoss 2013). Its efficiency, however, hinges on the appropriate determination of tariff levels. Based on a comparative assessment of renewable energy support policies in its member states, the European Commission concludes that "well-adapted feed-in tariff regimes are generally the most efficient and effective support schemes for promoting renewable electricity" (EC, 2008, p.3). Experiences in the emerging countries have shown that competitive bidding may be a suitable approach to identify the actual levels of such well-adapted feed-in tariffs (Becker \& Fischer, 2013, Pegels, 2014), and Germany could be well advised to 're-import' some such elements when reforming its own support scheme.

The German FiT scheme has been characterized by a long contract period (20 years), guaranteed grid priority, technology-specific tariffs on a degressive scale coupled with a direct selling option (market premium) and recently, provisions for tariff evolution in response to deployment trends (flexible ceiling). These design elements have created a stable investment environment and hence a strong readiness of capital markets to finance renewable energy projects at relatively low interest rates. Furthermore, the technology specificity-with differing FiT subsidy bands for each source of renewable energy-has had the advantage of encouraging the early deployment and upscaling of a wide spectrum of technologies. On the downside, it has not allowed for a focus on the most cost-efficient decarbonization technologies. A premium was thus placed deliberately on creating a broad foundation for various renewable energy technologies to develop and become commercially viable. However, this premium seems to have led to a bubble in the German solar PV manufacturing industry. Obviously, the critical challenge is to identify a sufficiently high subsidy level for investments to be triggered without creating excessively high policy rents (Pegels, 2014). This presupposes correct assumptions about future technological learning 
curves and price trends as a basis for taking well-informed decisions about an optimal tariff degression scale. The assumptions in the case of solar PV did not correspond to the considerable cost reductions of PV installations since 2009 (Bundesverband Solarwirtschaft, 2013).

Figure 9 seemingly presents an unequivocal outcome of the comparison between wind and solar support, showing the superior performance of wind energy for all indicators. However, the policy implications of these empirical findings are less clear-cut than they may appear at first glance. Should all eggs be put into the wind basket? In the direct comparison of wind and solar energy, the answer could be "yes," on grounds of cost-efficiency and broader benefits. Yet just like in the case of financial investments, there are advantages to be had from diversification. Hence, Figure 9 needs to be interpreted dynamically and from a systemic perspective. While wind energy currently performs better, it may be wise to also support solar PV and, for that matter, a variety of other sources of renewable energy. The technology learning curve of solar PV may still promise strong cost reductions, while wind energy is already mature (Diekmann et al., 2012b). The solar resource and thus deployment potential in other world regions may further support these reductions. Once a particular energy source achieves grid parity, deployment may increase steeply and give other performance indicators a boost as well. Technologies in their earlier stages may also hold a higher potential for innovation than their mature counterparts. This includes solar PV, but also such other early stage renewables as offshore wind or tidal and wave energy. Innovation as an aim of green industrial policy could thus benefit from the diversified support of renewable energy technologies.

However, diversification as such does not guarantee success in fostering innovation and competitiveness. Has the German policy-induced creation of a lead market led to a firstmover advantage or disadvantage? ? $^{9}$ Is it more a question of the early bird catching the worm or the second mouse getting the cheese? On the one hand, Germany has succeeded in building up world-class renewable energy technologies and has captured large segments of the world market. If well exploited, this lead position can secure competitiveness, employment and positive innovation dynamics for years to come. On the other hand, there are strong elements at play here of other countries appropriating part of the benefits of Germany's lead market role. This may be seen as a "successful internationalization of the photovoltaic strategy (and) ... a tribute to Germany's contribution to meeting global energy and climate challenges" (Diekmann et al., 2012a, p. 3). Alternatively and in a more pointed manner, the verdict may be that "German households have, through the renewable subsidies they pay, made the world a gift of solar technology which China has now been happy to exploit" (Buchan, 2012, p.4).

It is hard to escape the conclusion that the deployment of solar PV in particular has in recent years been out of line both with its long-term expansion potential and its reasonable relative

\footnotetext{
${ }^{9}$ For a more thorough discussion of lead market strategies see the results of the Lead Markets project of the Centre for European Economic Research (ZEW) at http://kooperationen.zew.de/en/lead-markets/project-description.html.
} 
weight within the renewable energy mix-in a country with less-than-ideal climatic conditions for heavy reliance on solar energy. Also, in the harsh judgment of Eicke Weber, Director of Fraunhofer ISE, “Germany's energy policy has created a market for photovoltaics-not an industry" (Paris Tech Review, 2012, p.5). This indicates that deployment under the soft conditions of heavy subsidies was given priority, without sufficient attention to forming an innovative industry pushing the technological frontier. In a nutshell: expansion was put above upgrading. In the analysis of the CEO of SunnysideUp, a German solar consultancy, too many companies decided to "deliver a standard product in a growing market ... we will lose if we just follow this race on a price level" (PV Magazine, 2011).

However, at the broader level of the energy system and within a supply scenario increasingly based on renewable energy, a variety of different intermittent sources in the electricity grid are required to support overall grid stability-the sun may shine when the wind does not blow. This contributes to security of supply, in particular if investments in transmission lines keep pace and connect geographically dispersed locations of renewable electricity generation. Unfortunately, German investments in grid expansion and solutions for electricity storage lag behind requirements. At the same time, Germany will need to deploy a variety of renewable energy sources if it takes the Energiewende seriously. The generation potential of onshore wind energy alone will not suffice to cover the full requirements of German electricity demand.

The systemic perspective cannot, however, be restricted to renewables: the energy sector must be seen in its entirety. The pace of German renewable energy deployment has taken many actors by surprise. This has led to unintended effects on energy planning, which in turn affect the overall aims of green industrial policy, in particular its environmental dimension. To safeguard energy security, Germany currently builds two energy systems in parallel: a base-load focused, centralized and fossil fuel-based system; and an intermittent, decentralized and renewable system. These systems increasingly interact. To compensate for the phasing out of nuclear power, the German government has decided to support highly efficient new coal and gas fired power stations, financing this support out of the Energy and Climate Fund (Deutsche Bundesregierung, 2012). Together with the unexpectedly high generation from renewable sources, Germany currently produces much more electricity than it consumes. In 2012, electricity exports exceeded imports by a record level of 22.8 terawatt hours (TWh), up from 6 TWh in 2011 and 17.6 TWh in 2010 (Statistisches Bundesamt, 2013). This oversupply, combined with low input prices and the low price of carbon emission certificates traded under the European Emissions Trading Scheme, reduces electricity prices to the extent where at times only the cheapest sources are still competitive, that is, hard coal and, in particular, lignite in the case of Germany. Lignite, however, is exceedingly damaging to the environment and human health. As a result, total German carbon dioxide emissions have been stagnating in the past four years, and even rising in 2012 (Umweltbundesamt, 2013b). Paradoxically, the rapid deployment of renewables thus does not currently lead to decreasing total greenhouse gas emissions. 
At the same time, the low electricity prices at the electricity stock exchange do not improve the competitive position of small and medium enterprises. Including 99 per cent of German enterprises and providing more than 60 per cent of jobs (May-Strobl \& Haunschild, 2013; BMWi, 2012), the Mittelstand is widely considered as the backbone of Germany's economy. However, their electricity prices are among the highest in Europe-at least partly due to the added cost of renewables (DIHK, 2012). The blow to the competitiveness of the largest electricity consuming companies is of course softened by exemptions from the electricity surcharge. These, however, call the equity of the current support system into question, since they raise the burden on households and small and medium enterprises.

To reach the broader aims of green industrial policy and manage the energy transition effectively, Germany will need to address the systemic challenges outlined above. Special emphasis is to be put on three broader dimensions: institutional fragmentation, interacting policy schemes and transformational alliances.

\section{Institutional Fragmentation}

As discussed by Zelli (2001) and Zelli and van Asselt (2013) in the context of climate governance, institutional fragmentation may have negative implications for effectiveness, legitimacy and fairness of policies. Since the promotion of wind energy and solar PV in Germany is part of a much more fundamental agenda of transitioning to a decarbonized development trajectory, issues of institutional fragmentation and distributed responsibilities are particularly relevant. The contribution of renewables to electricity generation has reached proportions that call for simultaneous policy attention to capacity expansion, competitiveness, technological innovation, grid management and storage capacities, i.e., a systemic perspective. However-and this may be surprising for a country often portrayed as a poster child of institutional effectiveness - the current institutional setup leaves a lot to be desired. Several federal ministries have important roles to play, and specialized subsidiary agencies are proliferating. There is thus a strong case for pooling the political responsibilities. This could be all the more important given that in the typical German scenario of a coalition government, there is a high likelihood of interlinked functions being spread across political party lines.

\section{Interacting Policy Schemes}

The FiT policy tool as the cornerstone of Germany's energy policy is not operating in complete isolation. In fact, it runs parallel to the European Emissions Trading System (ETS). The interactions between both policy spaces thus need to be analyzed. On the one hand, it can be argued that any FiT-induced lowering of $\mathrm{CO}_{2}$ emissions would lead to the availability of additional certificates, which, once sold, would generate corresponding emissions elsewhere. On the other hand, the political decision of where exactly to fix a cap for emissions may itself be partly influenced by anticipating trends of future renewables capacity (Lechtenböhmer \& Samadi, 2011, p. 10). In essence, the parallel operation of FiT and ETS will crowd out most of the former's emission reduction benefits-not, however, the other benefits it creates. 
A second dimension of policy interaction is related to transcending national boundaries. Quite obviously, the multiplicity of national FiT schemes, for example in the European Union, is an ineffective response to the potential of a unified European energy policy. A unified European, or even trans-Mediterranean, grid could largely balance out inherent grid instability caused by intermittent renewable energy sources. At the same time, there is a danger of a conceivable common approach being designed as the lowest common denominator of conflicting country interests. As a result, the more ambitious energy policy of Germany as a lead market for renewables may be severely compromised.

\section{Transformative Alliances}

Rightly or wrongly, green industrial policies in Germany are almost equated today with the energy transition. We are dealing with a national project of the first order. There are winners and losers, proponents and adversaries. In this economically and politically highly charged setting, the formation of transformative alliances and the definition of a compelling narrative are key (Schmitz et al., 2013). Such alliances may see unlikely bedfellows. Just as parts of the business establishment are embracing the transition and investing into the energy technologies of the future, heavy resistance is coming from parts of the traditional green movement. Alliances will thus have to go beyond conventional boundaries.

Having created the largest lead market for upscaling deployment and having brought down prices of renewables is not going to be a winning argument in the public discourse. The German FiT-driven renewables revolution may have been "arguably the most successful development cooperation programme ever in this field" (Hombach, 2013), yet this is not the yardstick used by the public at large when assessing costs and benefits. In Germany, any transformative alliance can only succeed if it builds on a platform of employment, competitiveness and innovation. Furthermore, the creation of decentralized energy systems and hence strengthened regional and local economic structures (above all in economically weak regions) should be highlighted more than hitherto. 


\section{References}

Andersen, C. (2012). Makers: The new industrial revolution. New York: Random House.

AGEE-Stat. (2012, July), Zeitreihen zur Entwicklung der erneuerbaren Energien in Deutschland.

Bazilian, M., Oneyeji, I., Liebreich, M., MacGill, I., Chase, J., Shah, J., Gielen, D., Arent, D., Landfear, D. \& Zhengrong, S. (2013). Re-considering the economics of photovoltaic power. Renewable Energy, 53 (2013), 329-338.

Becker, B., Fischer, D. (2013). Promoting Renewable Electricity Generation in Emerging Economies. In: Energy Policy, 56(C), pp. 446-455.

Bierenbaum, D., Frank, M., Lenox, M., \& Maheshwari, R. (2012, April). Winning the green innovation economy. An analysis of worldwide patenting. Batten Institute, University of Virginia, Greentech Innovation Series. Retrieved from http://www.darden.virginia.edu/web/uploadedFiles/Darden/Batten Institute/Publications/ Greentech 041212 Email.pdf (accessed 05 Oct 2013).

Boeckle, R., Dua, M., Henriques, D., Simon, P., \& Tronci, F. (2010, April 27). The German wind technology cluster. Microeconomics of competitiveness, Harvard Business School. Retrieved from http://www.isc.hbs.edu/pdf/Student Projects/Germany Wind Power 2010.pdf (accessed 20 December 2013).

Bointner, R. (2012). Energy R\&D expenditures and patents in selected IEA countries, Proceedings of the Venice IAEE European Conference 2012. Retrieved from http://www.eeg.tuwien.ac.at/eeg.tuwien.ac.at pages/publications/pdf/BOI PRO 20122 a bstract.pdf (accessed 02 March 2014).

Buchan, D. (2012, June). The Energiewende-Germany's gamble. The Oxford Institute for Energy Studies. SP 26. Retrieved from http://www.oxfordenergy.org/wpcms/wpcontent/uploads/2012/07/SP-26.pdf (accessed 02 March 2014).

Bundesministerium für Umwelt (BMU) (2012, August). Renewably employed. Short- and long-term impacts of the expansion of renewable energy on the German labour market.

Bundesministerium für Wirtschaft und Technologie (BMWi). (2012). German Mittelstand: Motor der deutschen Wirtschaft. Retrieved from http://www.bmwi.de/BMWi/Redaktion/PDF/Publikationen/factbook-germanmittelstand, property=pdf, bereich=bmwi2012, sprache=de, rwb=true.pdf $\quad$ (accessed 20 December 2013).

Bundesverband der Energie- und Wasserwirtschaft (BDEW). (2013, January 31). Erneuerbare Energien und das EEG: Zahlen, Fakten, Grafiken (2013). 
Bundesverband Solarwirtschaft. (2013). Statistische Zahlen der deutschen Solarstrombranche (Photovoltaik. Retrieved from www.solarwirtschaft.de/fileadmin/media/pdf/

20132 BSW Solar Faktenblatt Photovoltaik.pdf (accessed 02 March 2014).

Deutsche Bundesregierung (2012). Gelder aus dem Energie- und Klimafonds für das Förderprogramm für fossile Kraftwerke, Antwort der Bundesregierung auf die Kleine Anfrage der Abgeordneten Oliver Krischer, Sven-Christian Kindler, Hans-Josef Fell, weiterer Abgeordneter und der Fraktion BÜNDNIS 90/DIE GRÜNEN. Drucksache 17/8674, 14 February 2012. Retrieved from http://dipbt.bundestag.de/dip21/btd/17/086/

1708674.pdf (accessed 06 March 2014).

Deutsche Industrie- und Handelskammer (DIHK). (2012). Faktenpapier Strompreise in Deutschland. Retrieved from http://www.dihk.de/presse/jahresthema-2012/faktenpapierstrompreise.pdf (accessed 20 December 2013).

Diekmann, J., Kemfert, C., \& Neuhoff, K. (2012a). The proposed adjustment of Germany's renewable energy law-A critical assessment. DIW Economic Bulletin 2(6), 3-9.

Diekmann, J., Kemfert, C., Neuhoff, K., Schill, W. \& Traber, T. (2012b). Erneuerbare Energien: Quotenmodell keine Alternative zum EEG, DIW Wochenbericht, No.45/2012, 15-23.

Dosi, G., \& Galambos, L. (Eds.) (2013). The third industrial revolution in global business. Cambridge: Cambridge University Press.

Eichhammer, W., \& Walz, R. (2009, September). Indicators to measure the contribution of energy efficiency and renewables to the Lisbon targets. Karlsruhe: Fraunhofer Institute for Systems and innovation Research (Fraunhofer ISI). Retrieved from http://www.odysseeindicators.org/publications/PDF/report competitiveness indicators.pdf (accessed 06 March 2014).

European Commission. (2008, January). The support of electricity from renewable energy sources (Commission Staff Working Document). Brussels: European Commission. Retrieved from

http://ec.europa.eu/energy/climate actions/doc/2008 res working document en.pdf (accessed 02 March 2014).

Expertenkommission Forschung und Innovation (EFI) (Hrsg.) (2014). Gutachten zu Forschung, Innovation und technologischer Leistungsfähigkeit Deutschlands 2014, Berlin: EFI.

Fraunhofer ISE. (2012, May). Levelized cost of electricity. Renewable Energies. Freiburg. Retrieved from http://www.ise.fraunhofer.de/en/publications/veroeffentlichungen-pdfdateien-en/studien-und-konzeptpapiere/study-levelized-cost-of-electricity-renewable-

energies.pdf (accessed 20 December 2013). 
Fraunhofer ISI (2014). Expertenstatement: Wirkung des EEG - was ist die empirische Evidenz? Retrieved from http://www.isi.fraunhofer.de/isi-de/service/presseinfos/2014/EFIExpertenstatement.php?pk campaign=RSS-Feeds\&pk kwd=PM-RSS (accessed 06 March 2014).

Germany Trade \& Invest (GTAI). (2013). Industry Overview. The Photovoltaic Market in Germany. June 2013.

Haas, R., Panzer, C., Resch, G., Ragwitz, M., Reece, G., \& Held, A. (2011). A historical review of promotion strategies for electricity from renewable energy sources in EU countries. Renewable and Sustainable Energy Reviews, 15, 1003-1034.

Hallegatte, S., Fay, M., Vogt-Schilb, A. (2013). Green Industrial Policies, When and How. World Bank Policy Research Working Paper No. 6677. Retrieved from http://papers.ssrn.com/sol3/papers.cfm?abstract id=2346540 (accessed 06 March 2014).

Held, A., Haas, R. \& Ragwitz, M. (2006). On the success of policy strategies for the promotion of electricity from renewable energy sources in the EU. Energy and Environment, 17, 849868.

Hombach, B. (2013, January 15). Deutsche Stromrevolution in armen Ländern, Handelsblatt. Retrieved from http://www.handelsblatt.com/meinung/kolumnen/werber-rat/der-werberrat-deutsche-stromrevolution-in-armen-laendern/7616230.html (accessed 17 Dec 2014).

Krugman, P. (1994). Competitiveness: A dangerous obsession. Foreign Affairs, 2(73), 28-44.

Lechtenböhmer, S. \& Samadi, S. (2011, March). Brief analysis on the current debate about costs and benefits of expanding the use of renewable energies in electricity generation. Wuppertal Institute for Climate, Environment and Energy. Retrieved from http://boell.org/downloads/Wuppertal-engl.pdf (accessed 02 March 2014).

Lee, B., Iliev, I. \& Preston, B. (2009, September). Who owns our low carbon future? Intellectual property and energy technologies (Chatham House Report). London: Chatham House.

Lehr, U. \& Drosdowski, T. (2013, March). Soziale Verteilungswirkungen der EEG-Umlage (GWS Discussion Paper 2013/3). Retrieved from http://www.gwsos.com/discussionpapers/gws-paper13-3.pdf (accessed 02 March 2014).

Marsh, P. (2012). The new industrial revolution: Consumers, globalization and the end of mass production. New Haven: Yale University Press.

Matschoss, P. (2013). The German energy transition. Status, challenges and the Finnish perspective (FIIA Briefing Paper, No. 128). Retrieved from http://www.fiia.fi/en/publication/338/\#.Uq-AFPRDu9U (accessed 02 Feb 2014). 
May-Strobl, E., \& Haunschild, L. (2013). Der nachhaltige Beschäftigungsbeitrag von KMU. Eine sektorale Analyse unter besonderer Berücksichtigung der FuE-und wissensintensiven Wirtschaftszweige. Bonn: Institut für Mittelstandsforschung, Materialien Nr. 206. Retrieved from $\quad$ http://www.ifm-bonn.org//uploads/tx ifmstudies/IfM-Materialien-206 01.pdf (accessed 12 Feb 2014).

OECD (2013). OECD StatExtracts: Patents by Technology. Retrieved from http://stats.oecd.org/Index.aspx?DatasetCode=PATS IPC (accessed 15 June 2013).

O'Sullivan, M., Edler, D., Bickel, P., Lehr, U., Peter, F. \& Sakowski, F. (2013). Bruttobeschäftigung durch erneuerbare Energien in Deutschland im Jahr 2012 (BMU research project 0324052B). Retrieved from http://www.erneuerbareenergien.de/fileadmin/Daten EE/Dokumente PDFs/bruttobeschaeftigung ee 2012 bf.p df (accessed 17 Dec 2014).

Paris Tech Review (2012, April 13). The German solar energy crisis: Looking for the right incentive scheme. Retrieved from http://www.paristechreview.com/2012/04/13/germansolar-crisis/?media=print (accessed 02 March 2014).

Pegels, A. (Ed.). (2014). Green industrial policy in emerging countries. London: Routledge.

PV Magazine. (2011, March 18). Importance of PV module quality to increase. Retrieved from www.pv-magazine.com/news/details/beitrag/importance-of-pv-module-quality-toincrease 100002460/\#axzz22Up5WzYb (accessed 02 Feb 2014).

Rifkin, J. (2011). The third industrial revolution. How lateral power is transforming energy, the economy, and the world. New York: Palgrave Macmillan.

Schmitz, H., Johnson, O., \& Altenburg, T. (2013). Rent management-The heart of green industrial policy (IDS Working Paper no. 418). Retrieved from http://www.ids.ac.uk/files/dmfile/Wp418.pdf (accessed 13 Dec 2014).

Statistisches Bundesamt. (2013, February 2). Deutschland exportierte auch 2012 mehr Strom als es importierte (press release). Retrieved from http://www.destatis.de/DE/PresseService/ Presse/Pressemitteilungen/2013/04/PD13 125 51pdf.pdf (accessed 02 July 2014).

The Economist (2012, April 21). A third industrial revolution. Special Report Manufacturing and Innovation. Retrieved from http://www.economist.com/node/21552901 (accessed 17 Dec 2014).

Umweltbundesamt (2013a). Emissionsbilanz erneuerbarer Energieträger. Durch Einsatz erneuerbarer Energien vermiedene Emissionen im Jahr 2012, February 2013. Retrieved from http://www.umweltbundesamt.de/uba-info-medien/3761.html (accessed 02 Aug 2013). 
Umweltbundesamt (2013b). Treibhausgasausstoss in Deutschland 2012 - vorläufige Zahlen aufgrund erster Berechnungen und Schätzungen des Umweltbundesamtes, February 2013.

UNCOMTRADE (2013). United Nations Commodity Trade Statistics Database. Retrieved from http://comtrade.un.org/ (accessed 10 Nov 2014).

Zelli, F. (2011). The Fragmentation of the Climate Governance Architecture, in: Wiley Interdisciplinary Reviews: Climate Change 2(2), pp. 255-270.

Zelli, F., van Asselt, H. (2013). Introduction: The Institutional Fragmentation of Global Environmental Governance - Causes, Consequences and Responses, in: Global Environmental Politics 13(3), pp. 1-13. 